\title{
ISLAM AND GHRISTIANITY IN THE SUDAN
}

\author{
By ROLAND ALLEN
}

I HAVE lately been reading again Professor Westermann's article in the International Review of Missions for October 1912, and I have been greatly impressed by the fact that statements which when made by Dr Blyden in 1887' roused a storm of protest are repeated by Professor Westermann in 1912 as generally accepted truths. These are so fundamental, so far-reaching, that they demand the most serious consideration of all who direct, or are supporters of, Christian missions in the Sudan; for their general acceptance cuts deep into all our thought about the conduct of Christian missions in that great stretch of country from Gambia and Nigeria to the Nile.

Islam is advancing in the Sudan in some parts rapidly, in others more slowly, and it is advancing by peaceful propaganda. It is this peaceful penetration which Christian missions must meet, and therefore the sources of its success are matters which demand thought as well as mere expression. Islam is advancing more rapidly than Christianity, and if that advance is to be checked it must be understood. It is futile to imagine that it can be checked by methods designed for a very different warfare, a warfare against a paganism which was not advancing but perishing.

Professor Westermann says, ' In recent years Islam has probably made the most rapid progress in Nigeria, which has a population perhaps of sixteen millions, and especially in Southern Nigeria, which a few decades ago was almost

${ }^{1}$ Christianity, Islam and the Negro Race. London: Whittingham. 1887. 
entirely heathen.' But it is in Southern Nigeria that we have some of the oldest and best established Christian missions, and there has been peace in Southern Nigeria. This, then, is the problem which we have to consider, not why Islam advances where there are no Christian missions, but why it advances more rapidly than Christianity when both meet the same pagan tribes. What is it that attracts the African to Islam rather than to Christianity? Why can Islam penetrate rapidly into fresh fields whilst the army of Christ moves slowly ? Why is it that, as Professor Westermann says, 'At the present day all reports agree that it is the more intelligent part of the population which is favourably disposed towards Islam'? What is there in Islam which so powerfully attracts the African? Is it something which Christianity cannot, or will not, offer ?

1. Dr Blyden maintained that Islam offered the African social advancement, and Professor Westermann declares, ' That Islam represents for the African a higher stage of social organization than heathenism cannot be doubted by any one who has seriously studied the question on the spot.' 'When the negro adopts Islam, he at once becomes a member of a higher social class.'

2. Dr Blyden maintained that acceptance of Islam gave the African a new sense of dignity, new self-respect and self-reliance. 'There are numerous negro Mohammedan communities and states in Africa,' he said, 'which are self-reliant, productive, independent and dominant, supporting without the countenance or patronage of the parent country, Arabia, whence they derived them, their political, literary and ecclesiastical institutions.' $\mathrm{He}$ quoted with hearty approval a saying of $\mathrm{Mr}$ Bosworth Smith in 1874 that "Christian travellers, with every wish to think otherwise, have remarked that the Negro who accepts Mohammedanism acquires at once a sense of the dignity of human nature not commonly found even among those who have been brought to accept Christianity.' Since 1874 many have borne the same witness, and Professor 
Westermann repeats it. 'When a Negro adopts Islam . . . he quickly gains self-confidence and self-respect.... The despised bush Negro becomes a Mohammedan of position whom even the European involuntarily treats with respect. . . . Islam makes him a self-respecting African.'

3. Dr Blyden maintained that Islam brought education and intellectual enlightenment to the ignorant. "Mohammedanism and learning to the Muslim Negro were coeval.' He protested against the prejudice of missionaries who denied it. In the hyperbolical style which he loved he declared that 'a man might now travel across the continent from Sierra Leone to Cairo, or in another direction from Lagos to Tripoli, sleeping in a village every night, except in the Sahara, and in every village he would find a school,' and 'no sooner was he [the African] converted than he was taught to read, and the importance of knowledge impressed upon him.' Professor Westermann is more judicial. He points out that 'hardly more than five or ten per cent of the Mohammedan population are able to read and write', that 'the method employed is purely mechanical and the results are therefore correspondingly small,' and that 'book learning is the privilege of only a few who require it for the exercise of their profession'; but he too acknowledges that 'Islam is entitled to the honour of having introduced the art of reading and writing into the Sudan,' that 'every town and settlement has its teacher,' and that 'there have always been among the Mohammedans of the Sudan men of comprehensive learning in the Arabic-Islamic sense who have been active in the production of literature.'

4. Dr Blyden maintained that Islam progressed because it was propagated by natives voluntarily. It seems to be universally admitted that the Mohammedan trader is often a missionary. There is something in Islam which makes a convert a missionary; there is nothing to prevent him from acting freely as a missionary; there is no barrier 
(not even the -slightest) in the way of the admission of his converts. There is perfect freedom for him to convert and for them to enter the fold. And the desire to convert is generally present. Even where there is no direct preaching, the mere open observance of the acts of prayer is in itself a most powerful form of preaching. "The Mohammedan who enters a pagan village with his books and papers and rosaries, his frequent ablutions and regularly recurring times of prayers and prostrations, in which he appears to be conversing with some invisible being, soon acquires a controlling influence over the people.'

Professor Westermann says indeed that "religious activity in the sense of direct propaganda has been of far less importance for the islamization of the Sudan than political and social influences'; but he also says of the Moslem merchant that 'his superior manner of life, his richer clothing, his purer worship, are a daily sermon to the Negro,' and he takes for granted the fact that all Moslems at once accept a convert. 'He is admitted without any restrictions into the Mohammedan society.' All African Moslems welcome converts, and all are in this sense, while many are in a more active sense, missionaries. Islam is presented to natives by natives and converts are received into a native church. ' Above all,' says Professor Westermann, "Islam presents itself to the African in an African garb.' Its ' expansion has taken place automatically and without any direct effort.'

And as that society is self-propagating so it is obviously self-supporting and independent. Dr Blyden laid great stress upon this. 'In Sierra Leone the Mohammedans, without any aid from government-imperial or local-or any contributions from Mecca or Constantinople, erect their mosques, keep up their religious services, conduct their schools, and contribute to the support of missionaries from Arabia, Morocco or Fulah when they visit them. The same compliment cannot be paid to the negro Christians of that settlement.' 
5. Both Dr Blyden and Professor Westermann insist that the progress of Islam is not entirely due to the social advantages which conversion brings. They both proclaim their conviction that a true religious motive assists powerfully in that direction. Though Professor Westermann says, "Very frequently there is hardly any difference between Moslems and heathen. For both, magic is the religion of ordinary life'; yet he also says, 'The negro's conviction of the social superiority of Islam rests in the last resort on a religious basis, since he is unable to conceive of any striking exhibition of power as proceeding from other than a religious source." " "The Mohammedans know more of God than we do," and "Their God is stronger than ours," are statements which express his deep and deliberate conviction.' And again, 'The Mohammedan is always and essentially distinguished from the heathen by the value which he sets on his religion and his unreserved allegiance to it, and by his self-confidence in religious matters.'

One point of no little importance is expressed far more strongly by Professor Westermann than by Dr Blyden. It is the impression produced upon the pagans by the respect paid to Mohammedans by Europeans. Dr Blyden saw the self-reliance, self-respect and independent bearing of the Mohammedan Africans, but Professor Westermann traces it back to its source in ' the consciousness of membership in a world-wide religious society,' and measures the effect produced by the open recognition on the part of Europeans of that membership. "When a Negro adopts Islam he enters into a clearly defined relationship with Europeans.' 'The Mohammedans are regarded by the government as the most valuable element of the population and have all sorts of favours conceded to them.' 'Islam is officially recognized and respected by the colonial governments as a religious society, while heathenism is completely ignored.' 'In most of the European colonies it is taken for granted that those who join the army thereby become Mohammedans. The majority of the colonial 
governments maintain out of public funds schools in which the Mohammedan religion is officially assigned a place in the curriculum.' 'Moreover the Europeanized Negro never obtains among the whites that social equality to which Islam admits him readily. There are Europeans who take little pains to conceal the fact that the Christian " nigger" is as contemptible in their eyes as the bush nigger, and they not seldom take every opportunity of expressing their preference for Mohammedans.' And he adds, 'This sufficiently explains the fact that recently even natives who have received a Christian education have become advocates of Islam.'

Dr Blyden did indeed see the evil influence of the attitude which Europeans adopted towards native Christians. He was never tired of calling attention to it, and expressing his resentment at it, but he was rather concerned with its evil effect upon the Christians than with the effect produced upon the heathen by any sharp contrast between the attitude of Europeans to Moslems and to Christians, and so he did not treat this as of any importance in assisting Mohammedan propaganda. But that it has such an influence it is impossible to doubt. Europeans in Africa do instinctively adopt a different attitude towards the meanest Mohammedan from that which they show to native Christians. Islam is a militant religion and is always ready to take the sword against the infidel. It is not wise to stir slumbering fires by showing disrespect to any member of that religion. The writings and speech of all who have written about the government of the Sudan reveal that instinctive respect which is not untinged with fear.

When Dr Blyden wrote, a great outcry arose against him, and his facts were furiously controverted. Missionaries said then, as some of them often say to-day, that Islam advances not for the reasons which Dr Blyden suggested, but because it makes no moral demand on the pagans. It offers them the advantages of association with a powerful 
body without requiring any religious effort or putting any restraint upon their passions. Now it is surely plain that this reply to Dr Blyden must involve the denial of the evidence of progress which he adduced. Progress in civilization, in education, in self-respect ; zeal to propagate the faith, the power to attract 'the more intelligent part of the population' can scarcely be due to the fact that Islam makes no serious moral or intellectual or religious demands upon its converts. Because the demand made is not the kind of demand which Christian missionaries make, the demand for an instant and complete external break with long-established habits and customs, it does not follow that there is no demand. The demand is not external, and it is not instant : but if progress ensues there must be an internal and sufficient motive, and that motive must be found in the demands of the religion adopted. To-day all that we hear is the mere repetition of the phrase, 'Islam advances because it makes no moral demand.' Professor Westermann comes very near to repeating it himself when he says that ' in general one may say that the Mohammedan of the Sudan receives from his religion hardly any moral duties, but only religious commands, which exert no influence on his inward disposition'; but is it conceivable that religious commands which raise the social and general culture of a people; which abolish idolatry and human sacrifice; which diminish, if they do not abolish, the vice of drunkenness; which bring in education, and put an end to barbarous heathen customs; exert no influence upon the inward dispositions of those who submit to them? When 'the more intelligent part of a population,' when ' even natives who have received a Christian education,' are attracted to a religion, and become advocates of it, is it fair, is it even reasonable, to maintain that that religion advances because it puts no restraint upon the vices of its converts? Such an assertion seems to me to put a very severe strain upon our faith. Professor Westermann puts no such strain. Whatever he may say about the moral 
weakness of Islam, he repeats as the main causes of the advance of Mohammedanism precisely those things upon which Dr Blyden laid stress, and so far no answer has been given to him.

Since Professor Westermann repeats so definitely and precisely those very things which Dr Blyden set forth as the chief causes of Mohammedan advance, we may naturally inquire why some of the objections which were raised against Dr Blyden's statements have not been repeated to controvert Professor Westermann. This is no doubt partly due to the fact that much study has been given to the subject of Moslem propaganda since Dr Blyden wrote; but I cannot help thinking that in part it is due to the difference of attitude between these two men towards missionaries. Dr Blyden was a Christian, but he was also an African; and he lost no opportunity of drawing a contrast between the propaganda of Moslems and the propaganda of Christians, greatly to the disadvantage of the Christians. He felt bitterly the dominating, overbearing, contemptuous, patronizing attitude of white men for Africans, and he did not except the missionaries. He said 'the white man under a keen sense of the wrongs done to the Negro will work for him, will suffer for him, will fight for him, will even die for him, but he cannot get rid of a secret contempt for him.' He objected to the tendency of missionaries to state the savagery of the Africans in the blackest possible terms and to take up the attitude of one who must therefore eradicate, eradicate. He objected to their being 'the patrons of their disciples': they taught their converts servility; they pauperized them. There was among the native Christians none of that natural progress, that independence and self-respect, that native learning and original thought, that free natural expansion, which he so much admired in the Mohammedans. Missionaries, he said, made imitators rather than disciples. And he said all this not only repeatedly, but rather bitterly ; and missionaries who in their hearts knew that they were 
doing their utmost to uplift the natives resented it, and refused to listen to him.

Now Professor Westermann says the same thing but he says it very gently and very sparingly : so gently and so sparingly that he does not rouse anger : perhaps so gently and so sparingly that it is not even noticed; and so his paper has passed unchallenged. This is a great advantage if it enables us to look at the subject with calm minds, and to see the truth : it is a serious disadvantage if it leaves us self-complacently to pursue our course unchanged, imagining that no change on our part is necessary if we are to meet successfully a Moslem propaganda of this character.

And that is what we seem in danger of doing. Professor Westermann made no proposals for meeting the situation : he simply described it; but proposals have been made, and are being made now. $\mathrm{Mr}$ Roome in this Review for July 1916 quoted with great approval a statement made by Dr Robson at the World Missionary Conference at Edinburgh that 'the very first thing that requires to be done, if Africa is to be won for Christ, is to carry a strong missionary force right across the centre of Africa to bar the advance of the Moslem.' Similarly Dr Patton in the Missionary Review of the World for January 1918 suggested that the true method of meeting the advance of Islam in Africa involved the co-operation of three societies now working in the Sudan, and the establishment of their work upon a solid foundation both as to method and equipment. 'In my opinion,' he said, 'a few centres well occupied will count for more than a string of feeble stations stretched over the vast territory from the Niger to the Nile. It is particularly important that well-equipped medical stations should be located at strategic points at the earliest possible date.' At the present moment, I believe several societies are planning a division of the Sudan between them, that they may advance each on its own lines and so establish stations at important points right across the country. 
Now these schemes have all one common characteristic ; they are all based on the assumption that the Moslem advance can be met by a great expenditure of money and the multiplication of foreign missionaries and of stations. If I may use a military metaphor borrowed from the Boer War, they propose to stop the invasion of the heart of Africa by a system of blockhouses manned by foreigners. Suppose that it could be done : the establishment of these stations is not only a slow and costly business but it is apt to meet with opposition from governments. But suppose that no difficulty stood in the way, we are still face to face with the proposition with which this paper opened, that missionary stations do not always convert the pagans as fast as the Mohammedan influence, that Mohammedans increase in numbers more rapidly than Christians even where there are excellent missionaries; and there is no reason to suppose that the same thing will not happen again.

What is it that we have to meet? We have to meet a religious propaganda which civilizes by admitting those who have least civilization into the society of those who have most, and allowing them to absorb as they can the higher civilization; which enlightens and educates by establishing schools of the simplest possible character, in which all teaching is rooted and grounded in one book and that one book the sacred book, so that every school is first and before all things a school of religion; which begins by accepting as converts any who are willing to learn even a little, and makes the converts feel that by mere union with the new religious body they are raised far above all their pagan neighbours, whilst entrance into that body is not impossibly difficult for any pagan; which gives the convert, simply as a convert, a position which he can maintain not only against his heathen friends and neighbours, but in the face of Europeans, and a position which he holds independently of any foreign support; which while it civilizes does not force a premature adoption of 
any foreign civilization; which begins by insisting that all the religious life of the converts shall be self-supporting, and more than self-supporting, independent of external aid, and more than independent, never receiving other men's charity but always giving of their own wealth, and that however poor the converts may be; which advances 'automatically,' as Professor Westermann says.

Can we expect to meet that by a propaganda which puts white foreign missionaries always in the first place, and teaches the whole native Christian community to depend upon them; which, to quote rather the mild speech of Professor Westermann than the fierce indignation of Dr Blyden, 'destroying his civilization and seeking to substitute our own,' is in danger of 'turning the Negro into a mere caricature of the European'?

And yet is it inconceivable that Christianity has within it that secret inner strength which grows of itself ? Why does Dr Blyden contrast the Christian propaganda with the Mohammedan on every one of these deep inner things, growth in native civilization and learning, self-respect, independence of character and the like, and always to the disadvantage of the Christian; and why does Professor Westermann gently hint the same thing ? Is it the fault of our religion? or is it the fault of our teaching ? or is it the fault of our practice? Are we to acknowledge that those things which make the more intelligent Africans 'see in Islam the religion of the modern African' are really alien to the spirit of Christianity? Are we to believe that it is impossible and undesirable that Africans should be attracted to Christianity because they saw Christian Africans finding in Christianity all, and more than all, that those who become Mohammedans seem to find in Islam ? Is it not true that Christianity, without the forms of western civilization, should be a civilizing power ? Is it not true that Christianity should inspire a sense of the dignity of men, and that the presence of the Holy Ghost should create in those in whom $\mathrm{He}$ dwells a true sense of 
self-respect ? Is it not true that fellowship in the Church of Christ should be a bond of union deeper and stronger than anything known to the Mohammedan? Is it not true that there is in Christianity something to inspire a zeal for the spread of the Gospel better than anything to be found in Islam? Is it not true that the Church might grow in Africa automatically?

Obviously the fault lies with us; and obviously we ought to put the consideration of that fault, the search for its source, the amendment of it, in the first place in our thoughts, and to think more of that than of the establishment of stations, the multiplication of workers, the increase of funds. These things are all superficial; the other is fundamental. But the superficial is always more easy than the fundamental. This is profoundly difficult. It demands careful penitential consideration; for any serious attempt to meet it involves not merely the reconstruction of our methods of procedure, but a spiritual change. One thing is certain. We cannot alter the attitude of the majority of our countrymen to the native Christians in a moment. We cannot make them welcome converts, or treat them as Christian brethren ought to be treated. Native self-respect will not easily be built up in an atmosphere of insolence, supercilious scorn, or even of patronage. We cannot alter the masterful, dominating character of the western folk to whom we belong. With our eyes wide open to its evils we find it almost impossible to control it in ourselves. Nothing is so hard for us as to respect our converts, and to show respect, the respect which helps them to true Christian self-respect.

A free native Church conscious of its royal prerogatives ${ }^{1}$ might beat back Islam : a dependent one cannot, and will not even attempt it : a foreign force however great its efforts, however large its resources, cannot succeed by itself. It cannot succeed even by employing natives to assist it. Until the native Christians learn to respect

1 I Pet. ii. 9. 
themselves, to feel that they can advance the Church by their own unaided efforts, we shall never be able to meet the Moslem propaganda on equal terms. If there is truth in the case set forth by Professor Westermann this is the inevitable conclusion, as it seems to me, and it is to this that I desire to call the attention of thoughtful people.

\section{Roland Alien}

[This article will be made the basis of an inquiry into the subject of which it treats and the results will be published in subsequent numbers of the Review.-ED.] 